\title{
Effect of the addition of psyllium (Plantago Ovata Forsk) on the total and bioaccessible concentration of the minerals sodium and potassium in frozen banana
}

\section{pulp}

\author{
Efeito da adição de psyllium (Plantago Ovata Forsk) na concentração total e bioacessível dos \\ minerais sódio e potássio na polpa de banana congelada \\ Efecto de la adición de psyllium (Plantago Ovata Forsk) sobre la concentración total y bioaccesible \\ de los minerales sodio y potasio en la pulpa de banano congelada
}

Received: 06/08/2021 | Reviewed: 06/17/2021 | Accept: 06/23/2021 | Published: 07/14/2021

Elisângela Aparecida Nazario Franco
ORCID: https://orcid.org/0000-0003-3057-9343
E-mail: elinazario@ @otmail.com
Davstituto Federal de Educação, Ciência e Tecnologia de Brasía, Brazil
Dilliam Hidalgo Chávez
ORCID: https://orcid.org/0000-0003-4319-1962
Universidade Federal Rural do Rio de Janeiro, Brazil
E-mail: davyhw76@ gmail.com
Carlos Alberto Kenji Taniguchi
ORCID: https://orcid.org/0000-0002-1280-8678
Embrapa Agroindústria Tropical, Brazil
E-mail: carlos.taniguchi@embrapa.br
Antonia Barbosa de Lima
ORCID: https://orcid.org/0000-0002-3134-9518
Instituto Federal de Educação, Ciência e Tecnologia do Ceará, Brazil
E-mail: antoniabarbosa_2005@ yahoo.com.br
Maria do Socorro Rocha Bastos
ORCID: https://orcid.org/0000-0002-5648-5241
Embrapa Agroindústria Tropical, Brazil
E-mail: socorro.bastos@embrapa.br
Nathália Ramos de Melo
ORCID: https://orcid.org/0000-0002-9533-506X
Universidade Federal Rural do Rio de Janeiro, Brazil
E-mail: nathaliarm@id.uff.br

\begin{abstract}
Increased blood pressure is one of the main risk factors for cardiovascular disease. The World Health Organization (WHO) recommends that sodium intake should be moderate and potassium intake can be increased, as its intake is associated with a lower incidence of cardiovascular disease. Banana is a fruit rich in potassium and has large postharvest losses due to its perishability. The production of frozen pulps is an alternative to reduce these losses. To add nutritional and functional benefits to the fruit pulp, it is possible to add soluble fiber, since its high intake is known to have a protective effect against cardiovascular disease and its intake by individuals does not meet the recommended minimum. There is evidence that psyllium dietary fiber contributes to lowering blood pressure, lowering cholesterol, lowering blood glucose and its incorporation into foods may offer health benefits such as preventing high blood pressure. Knowing that sodium and potassium intake is related to blood pressure, this study aimed to investigate the content of the minerals sodium and potassium in frozen banana pulp added with psyllium and to verify the concentrations of bioaccessibility in in vitro digestion. Our results showed that the addition of psyllium contributed to an increase in the content of the minerals potassium and sodium and that after the simulated digestions we verified that the final concentrations of the mineral potassium are in agreement with other results present in the literature, we also saw that despite increasing the sodium content, the final concentration of the dialysate (which would be absorbed by the human body) was $0.17 \%$, being very low and ideal for preventing high blood pressure.
\end{abstract}

Keywords: Blood pressure; Cardiovascular disease; Dietary fiber; Chronic disease; Functional food.

\section{Resumo}

O aumento da pressão arterial é um dos principais fatores de risco para as doenças cardiovasculares. A Organização Mundial da Saúde (OMS) recomenda que o consumo de sódio deve ser moderado e o consumo de potássio pode ser 
aumentado, pois sua ingestão está associada a uma menor incidência de doença cardiovascular. A banana é uma fruta rica em potássio e apresenta grandes perdas pós colheita devido sua perecibilidade. A produção de polpas congeladas é uma alternativa para reduzir essas perdas. Para agregar benefícios nutricionais e funcionais à polpa de frutas é possível adicionar fibras solúveis, visto que sua alta ingestão é conhecida por ter um efeito protetor contra doença cardiovascular e sua ingestão pelos indivíduos não atende ao mínimo recomendado. Há evidências que a fibra dietética psyllium contribui para a redução da pressão arterial, redução do colesterol, redução da glicemia e sua incorporação nos alimentos pode oferecer benefícios para a saúde como a prevenção da hipertensão arterial. Sabendo que o consumo de sódio e potássio tem relação com a pressão arterial este estudo teve por objetivo investigar o conteúdo dos minerais sódio e potássio em polpa congelada de banana adicionada de psyllium e verificar as concentrações das bioacessibilidades na digestão in vitro. Nossos resultados mostraram que a adição do psyllium contribuiu para um aumento no teor dos minerais potássio e sódio e que após as digestões simuladas verificamos que as concentrações finais do mineral potássio está de acordo com outros resultados presente na literatura, vimos também que apesar de aumentar o teor de sódio a concentração final do dialisado (o que seria absorvido pelo organismo humano) ficou em $0,17 \%$, sendo muito baixo e ideal para prevenir a hipertensão arterial.

Palavras-chave: Pressão arterial; Doença cardiovascular; Fibra alimentar; Doença crônica; Alimento funcional.

\section{Resumen}

El aumento de la presión arterial es uno de los principales factores de riesgo de enfermedad cardiovascular. La Organización Mundial de la Salud (OMS) recomienda que la ingesta de sodio sea moderada y se pueda incrementar la ingesta de potasio, ya que su ingesta se asocia con una menor incidencia de enfermedad cardiovascular. El banano es una fruta rica en potasio y tiene grandes pérdidas poscosecha debido a su perecibilidad. La producción de pulpas congeladas es una alternativa para reducir estas pérdidas. Para agregar beneficios nutricionales y funcionales a la pulpa de la fruta, es posible agregar fibra soluble, ya que se sabe que su alto aporte tiene un efecto protector contra las enfermedades cardiovasculares y su ingesta por parte de los individuos no alcanza el mínimo recomendado. Existe evidencia de que la fibra dietética de psyllium contribuye a reducir la presión arterial, reducir el colesterol, reducir la glucosa en sangre y su incorporación a los alimentos puede ofrecer beneficios para la salud, como prevenir la hipertensión arterial. Sabiendo que la ingesta de sodio y potasio está relacionada con la presión arterial, este estudio tuvo como objetivo investigar el contenido de los minerales sodio y potasio en la pulpa de banano congelada con psyllium y verificar las concentraciones de bioaccesibilidad en la digestión in vitro. Nuestros resultados mostraron que la adición de psyllium contribuyó a un aumento en el contenido de los minerales potasio y sodio y que luego de las digestiones simuladas comprobamos que las concentraciones finales del mineral potasio están de acuerdo con otros resultados presentes en la literatura, también Vio que a pesar de aumentar el contenido de sodio, la concentración final del dializado (que sería absorbido por el cuerpo humano) era del $0,17 \%$, siendo muy baja e ideal para prevenir la hipertensión arterial.

Palabras clave: Presión arterial; Enfermedad cardiovascular; Fibra dietética; Enfermedad crónica; Comida funcional.

\section{Introduction}

Chronic Non-Communicable Diseases (NCDs) account for $72 \%$ of deaths worldwide (Thakur, Paika, \& Singh, 2020) and among the main ones are cardiovascular diseases. The most common risk factors are increased blood pressure, increased blood glucose and increased cholesterol (Bennett et al., 2018).

High potassium intake is associated with a lower incidence of cardiovascular disease as it reduces blood pressure (Olde Engberink, van den Born, Peters-Sengers, \& Vogt, 2020) and the World Health Organization (WHO) recommends for the adult population an intake of this mineral of at least $90 \mathrm{mmol} / \mathrm{day}$ (3,510 $\mathrm{mg} /$ day) (WHO, 2012).

According to the WHO (2003) the interest around the consumption of potassium grows due to its utility in public health and there is a need to find viable and economic actions that increase the intake of this mineral. In this way, the WHO recommends increasing the intake of potassium through food in order to reduce blood pressure and the risk of cardiovascular diseases.

The consumption of certain vegetables with a high potassium content is associated with a decrease in the risk of arterial hypertension and stroke. In societies where there was a reduction in the consumption of fruits and vegetables and the increase in the consumption of industrialized foods, it was observed that this change in eating habits caused an increase in sodium consumption (Na) that maintains a direct relationship with the increase in blood pressure(Weaver, 2013). 
Sodium and potassium are important for the water balance in our body. Sodium retains fluids and potassium eliminates, leaving only the necessary amount, they are fundamental for muscle contraction and relate to blood pressure (Sun \& Sun, 2018).

The WHO advises that sodium consumption for the adult population should be moderate $(2 \mathrm{~g} /$ day), since its excessive consumption can cause hypertension and cardiovascular diseases. In Brazil its consumption exceeds the recommended (Orlando, Rebellato, Silva, Andrade, \& Pallone, 2020).

According to Ezzati et al. (2018) to the consumption of fruits and vegetables may be among the potential factors for lowering blood pressure. Among the fruits, the banana (Musa spp.) is a source of potassium and deserves attention for being consumed worldwide due to its sensory acceptance (Sheng et al., 2010), however, it is a fruit that has great losses due to its high perishability (Md Nor \& Ding, 2020). More than 48 million tons per year are lost worldwide (Molina-Ramírez, CañasGutiérrez, Castro, Zuluaga, \& Gañán, 2020).

An alternative to prevent waste is the production of frozen pulps, in addition to practical consumption. Its market is expanding and processing the fruits into frozen pulps adds profitable value to the product. The freezing process preserves the physical, nutritional and sensory properties of fruit pulp and its consumption has health benefits (Orqueda et al., 2021).

In addition to fruits, high dietary fiber intake is known to have a protective effect against cardiovascular disease, few individuals achieve the desired amount of fiber in their diets (Anderson et al., 2009).

To add nutritional and functional value to the frozen fruit pulp psyllium can be added, since it will increase the fiber content in the product without increasing caloric intake (Bernstein, Titgemeier, Kirkpatrick, Golubic, \& Roizen, 2013).

Psyllium has benefits that are already well known in the literature due to its high content of soluble fiber contributing to add nutritional, functional and sensory value to foods. Among the functional properties are the reduction of blood glucose, reduction of cholesterol, relief of constipation, aid in weight loss by providing satiety among others (Franco et al., 2020). In Brazil, Brazilian Health Regulatory Agency (ANVISA) authorizes to inform on the label of products that present at least $3 \mathrm{~g}$ of psyllium per serving the health claim that: "the consumption of the product allied to healthy habits decrease the absorption of fat" (Brazil, 1999).

There is evidence that psyllium contributes to the reduction of blood pressure (Bernstein et al., 2013) and the incorporation of it in diets can offer benefits for the prevention of arterial hypertension and as a consequence the reduction of the risk of cardiovascular disease. To date, there is no knowledge about the mechanism of action between fibers and their effect on blood pressure. There are some reports that have suggested that the benefit of fibers in lowering blood pressure would be related to their viscosity, which provides a slow absorption of some nutrients and this affects some metabolic indices, such as cholesterol, body weight and insulin resistance (Khan et al., 2018).

As far as we know, no study on the relationship in the consumption of soluble fibers and the regulation of pressure suggested that this benefit could also be related to the content of potassium and sodium in them. There are few studies on the composition of minerals in soluble fibers and no reports on the bioaccessibility of minerals $\mathrm{K}$ and $\mathrm{Na}$ in banana and psyllium have been found in the literature so far.

Although there are many studies on bioaccessibility, the literature is scarce regarding the bioaccessibility of minerals, studies on the bioaccessibility of polyphenols compounds are more common (Pereira et al., 2018).

Bioaccessibility refers to a fraction of a nutrient or a compound that is released from its matrix in the gastrointestinal tract, becoming available for intestinal absorption, whereas bioavailability is the amount of a nutrient or compound present in a food that the body can absorb in the intestine (Fernandez et al, 2009). 
It is known that our body does not absorb the total concentration of nutrients from the foods that are ingested, due to this many bioaccessibility studies are under development so that one can have a better knowledge about the levels of elements (nutrients, phenolic compounds, metals) that is absorbed by the intestinal epithelium (Pereira et al., 2018).

This study aimed to investigate the effect of psyllium addition on physicochemical characteristics and verify the bioaccessibility of the minerals sodium and potassium in frozen banana pulp added psyllium.

\section{Methodology}

\subsection{Chemicals and reagents}

Pepsin, $\alpha$-amylase, Pancreatin and bile salts were acquired from Sigma-Aldrich (São Paulo, Brazil). Hydrochloric acid $(\mathrm{HCl})(37 \% \mathrm{~m} / \mathrm{m})$, sulfuric acid $\left(\mathrm{H}_{2} \mathrm{SO}_{4}\right)$, ethanol and methanol were purchased from Neon (São Paulo, Brazil). Phenolphthalein and sodium hydroxide were acquired from Cequímica (Fortaleza, CE).

\subsection{Material}

The banana (Musa spp.) of the cultivar "Prata" was acquired in the local market of the municipality of Iguatu/CE and was in the stage of maturation number 6 (Von Loesecke, 1950) and without treatment with ethylene.

The psyllium used in this research had 95\% purity and contained about $80 \%$ dietary fiber, was purchased in a market in the municipality of Iguatu/CE. Citric acid (INS 330) and ascorbic acid (INS 300) were purchased from Pantec Aditivos $e$ Ingredientes, Brazil.

\subsection{Preparation of samples}

The bananas were sanitized in running water and left in chlorinated solution at $200 \mathrm{ppm}$ for 15 minutes, rinsed and subjected to natural drying for subsequent removal of the peels. The bananas were placed in a pulper (Braesi brand model DES-60/1) and then the other ingredients were added according to Table 1.

Table 1. Formulation of frozen banana pulp.

\begin{tabular}{lllll}
\hline Sample & Psyllium & Banana & Citric acid & Ascorbic acid \\
\hline Pulp 0\% & 0 & $99,6 \%$ & $0,2 \%$ & $0,2 \%$ \\
Pulp 3\% & $3 \%$ & $96,6 \%$ & $0,2 \%$ & $0,2 \%$ \\
\hline
\end{tabular}

Source: Authors.

Added pulps of 3\% psyllium and pulps without added psyllium were prepared. Ascorbic acid and citric acid were used to prevent enzymatic darkening and assist in product conservation (Brazil, 2013).

The pulps were stored at $-8^{\circ} \mathrm{C}$ and triplicate analyses took place the next day.

\subsection{Measurement of $\mathrm{pH}$}

The $\mathrm{pH}$ was determined by direct reading, in potentiometer, calibrated with each use with buffer solutions of $\mathrm{pH} 4.0$ and 7.0 according to IAL (2008).

\subsection{Titratable total acidity (TTA)}

The TTA was determined by the volumetric titration method with indicator following the IAL methodology (2008). 


\subsection{Color determination}

The instrumental color determination of the samples was performed using colorimeter Chroma Meter CR-400 (Konica Minolta, Japan), using illuminant D65 and geometry 45/0, and the color values were expressed in the CIELAB system. The values of $\mathrm{L} *$ (Luminosity), $\mathrm{a}^{*}$ (red-green component) and $\mathrm{b}^{*}$ (yellow-blue component) were obtained directly from the colorimeter. $\mathrm{L} *$ ranges from 0 to 100 , in which the value 0 indicates black (or dark color) and 100, white (light color). All measurements were carried out at a temperature of $20^{\circ} \mathrm{C}$ in the same light conditions (measuring area of $50 \mathrm{~mm}^{2}$ ) and replicated 6 times (Lawless; Heymann, 1998).

\subsection{Determination of the minerals sodium (Na) and potassium (K)}

Before spectrometric analysis, the samples were subjected to wet ash following the microwave digestion procedure in which $500 \mathrm{mg}$ of sample was weighed directly into the digestion container. Nitric acid (HNO3) at $65 \%$ (v/ v) (5 mL) and $30 \%$ hydrogen peroxide $(\mathrm{H} 2 \mathrm{O} 2)(\mathrm{v} / \mathrm{v})(2 \mathrm{~mL})$ were added to the samples, the vessels were covered and placed in the rotator body of the microwave oven (Milestone MLS 1200 Mega oven-Milestone, Bergamo, Italy) and the digestion program was carried out. The digestion conditions were: $1 \mathrm{~min}$ at $250 \mathrm{~W}$ (mild oxidation of organic matter); $1 \mathrm{~min}$ at $0 \mathrm{~W}$ (proceeding from reaction without adding energy to avoid temperature leaks and overpressures); $5 \mathrm{~min}$ at $250 \mathrm{~W}$ (termination of mild oxidation of organic compounds); $5 \mathrm{~min}$ at $400 \mathrm{~W}$ and $5 \mathrm{~min}$ at $600 \mathrm{~W}$ (final termination of oxidation processes applying greater power). After cooling, the digested samples were transferred to volumetric vials and diluted to $50.0 \mathrm{~mL}$ using deionized water and then transferred to $50.0 \mathrm{~mL}$ polyethylene vials.

The macroelements sodium $(\mathrm{Na})$ and potassium $(\mathrm{K})$ were determined by inductively coupled Plasma atomic emission spectrometry (ICP-AES) in a thermo scan trace (Thermo Jarrell Ash Corporation, Franklin, USA); 588,995 nm for Na and $769,897 \mathrm{~nm}$ for K, using a standard technique (Jarrell Ash Corporation, 1995).

\subsection{Simulated gastrointestinal digestion in vitro (bioaccessibility)}

In this study, the salivary digestion simulation was not carried out, considering that the amylase enzyme acts in the breakdown of starch molecules, and in this study the pulps were prepared with ripe banana, with sugars being its main carbohydrate.

A simulated gastric fluid was used for digestion according to the procedures implemented by Moura and CanniattiBrazaca (2006). The simulation of gastrointestinal digestion was performed with pepsin solubilized with $\mathrm{HCl} 0.1 \mathrm{~mol} \mathrm{~L}^{-1}$ during the gastric phase and bile-Pancreatin salts, solubilized with $\mathrm{NaHCO}_{3} 0.1 \mathrm{~mol} \mathrm{~L}^{-1}$ in the intestinal phase.

Twenty grams of each sample of the pulps were weighed and added in $100 \mathrm{~mL}$ of $\mathrm{HCl} 0.01 \mathrm{~mol} \mathrm{~L}^{-1}$, the $\mathrm{pH}$ was adjusted to 2 with $\mathrm{HCl}$ solution $2 \mathrm{~mol} \mathrm{~L}^{-1}$ and added $3.2 \mathrm{~mL}$ of pepsin in the middle, and the sample was placed in a thermostatic bath with stirring at $37{ }^{\circ} \mathrm{C}$ for 2 hours to simulate the digestion of food in the stomach.

After adjusting the $\mathrm{pH}\left(0.5 \mathrm{~mol} \mathrm{~L}^{-1}\right.$ of $\mathrm{NaOH}$ up to $\left.\mathrm{pH} 7.5\right)$ dialysis membranes $(3321 \mathrm{~mm}$, molecular weight: 12,000-16,000, porosity: 25 Angstrons - InLab, Brazil) containing $0.1 \mathrm{~mol} \mathrm{~L}^{-1} \mathrm{NaHCO} 3$ equivalent to titratable acidity were added to the gastric solution in a thermostatic water bath with stirring at $37{ }^{\circ} \mathrm{C}$ for 30 minutes. After this time, it was added $5.0 \mathrm{~mL}$ of Pancreatin solution and bile salts and stirred in a bath at $37^{\circ} \mathrm{C} / 2 \mathrm{H}$. This step simulated digestion in the intestine.

At the end of this step, the contents of the inside of the membranes (dialysated) were collected and stored in amber glass tubes and the samples were stored at $-8{ }^{\circ} \mathrm{C}$ until the moment of analysis.

For the correct quantification of minerals, it was performed simultaneously with the samples analytical whites containing the same reagents and conditions used in digesting them. 
The dialysis samples were analyzed in triplicate by ICP OES for the determination of potassium $(\mathrm{K})$ and sodium (Na). The bioavailable percentage was calculated by the concentration of each mineral released in the in vitro digestion process in relation to the total concentration of each element.

\subsection{Data Analysis}

The percentage (\%) of bioaccessibility was calculated according to the equation: BF (\%)= BE/TE x 100, onde BF é a porcentagem da fração bioacessível, BE é a fração do elemento bioacessível (mg 100 g -1), dada pela concentração de um elemento encontrado nos extratos gástricos ou gastrointestinais, e TE é a concentração total do elemento (mg $100 \mathrm{~g}-1)$ nas polpas.

The results of the total contents of the samples and the percentages of the bioaccessible fractions were presented as mean and standard deviation. Analysis of variance (ANOVA) and Tukey test $(\mathrm{p}<0.05)$ were calculated to verify significant differences between the results. All statistical analyses were performed with the software Statistica v. 8.0 (StatSoft, 2007).

\section{Results and Discussion}

\subsection{Physicochemical properties of the pulps}

The effect of adding $3 \%$ psyllium on physicochemical properties in frozen banana pulp is shown in Table 2.

Table 2. Physico-chemical results of frozen banana pulp.

\begin{tabular}{lll}
\hline Analyzes & Banana pulp & Banana pulp with psyllium \\
\hline $\mathrm{pH}$ & $4.21 \pm 0.01^{\mathrm{b}}$ & $4.25 \pm 0.02^{\mathrm{a}}$ \\
ATT $^{*}$ & $1.02 \pm 0.01^{\mathrm{a}}$ & $1.02 \pm 0.01^{\mathrm{a}}$ \\
Color & & \\
$\mathrm{L}^{*}$ & $71.5 \pm 0.57^{\mathrm{a}}$ & $64.26 \pm 0.19^{\mathrm{b}}$ \\
$\mathrm{a}^{*}$ & $2.14 \pm 0.53^{\mathrm{b}}$ & $4.8 \pm 0.06^{\mathrm{a}}$ \\
$\mathrm{b}^{*}$ & $21.66 \pm 0.48^{\mathrm{a}}$ & $21.92 \pm 0.19^{\mathrm{a}}$ \\
\hline
\end{tabular}

\footnotetext{
* ATT-titratable total acidity in malic acid (\%)

Different letters on the same line indicate that there was a significant difference by the Tukey test $(\mathrm{p}<0.05)$.

Source: Authors.
}

The addition of psyllium was responsible for the significant increase in $\mathrm{pH}$, but did not change for titratable acidity values. Table 2 showed the result of the concentration in malic acid, but we also verified the concentration of citric acid in the pulp and in both were found the equivalent of $1.1 \mathrm{~g} / 100 \mathrm{~g}$ of citric acid. The increase in $\mathrm{pH}$ probably must have been due to the fact that psyllium has a pH of 4.46 (Rao, Warrier, Gaikwad, \& Shevate, 2016).

According to results found in the literature, banana is a fruit of low acidity, the values for $\mathrm{pH}$ and for total acidity is variable and depends on the degree of ripening post-harvest and the cultivar. It turns out that some studies have shown similar results for bananas (Musa spp.), reporting that the pH of bananas ranged from 4.3 to 5.5 (Etienne, Génard, Bancel, Benoit, \& Bugaud (2013) and Bugaud, Maraval, Daribo, Leclerc, and Salmon (2016). The acidity in malic acid was investigated in the studies of Yap, Fernando, Brennan, Jayasena, and Coorey (2017) in bananas of the Cavendish cultivar and of Dotto, Matemu, and Ndakidemi (2019) the cultivar bananas of the Earth and the results showed values of $1.5 \%$ to $2.3 \%$ being similar to that found in this study $(1.02 \%)$. 
It is noteworthy that in this study, citric and ascorbic acids were added to the pulp in order to avoid enzymatic darkening, being allowed by Resolution No. 8 of March 6, 2013 (Brazil, 2013). Even the concentration of the addition of acids being low $(0.2 \%$ each) may have affected on the total acidity and $\mathrm{pH}$ content.

According to normative instruction number 37, of October 1, 2018, the identity and quality standard for banana pulp must meet the minimum characteristics of $\mathrm{pH} 4.1$ and total acidity expressed in citric acid 0.20 (g / $100 \mathrm{~g}$ ) (Brazil, 2018), our $\mathrm{pH}$ and acidity results meet the required standard, being $\mathrm{pH} 4.2$ and total acidity in citric acid 1.1 (g/ $100 \mathrm{~g})$.

As presented in Table 2, the results for the color measurement showed that the addition of $3 \%$ psyllium significantly decreased the value of $L^{*}$ (darker samples), this effect on darkening may be due to the color of psyllium being darker than the pulp of the banana. The darkening of the pulp with the addition of psyllium is related as the significant increase in $a *$ values, since it had no significant effect on $b^{*}$.

There are few studies with the addition of psyllium in food products, but it was verified that similar results were presented in studies Figueroa and Genovese (2019) in which psyllium fiber was used combined with other fibers in fruit jelly and showed a reduction in $L^{*}$ values. In the studies of Raymundo, Fradinho, and Nunes (2014) the addition of psyllium in cookies also resulted in a darkening with reduction in luminosity values. Another study that showed similar results in the decrease of $L^{*}$ values was with the use of psyllium in the production of a biodegradable film (Sukhija, Singh, \& Riar, 2016).

Our results in the determination of color for banana pulp without the addition of psyllium were similar with the results of Yap et al. (2017) in banana puree from the Cavendish cultivar at the maturation stage 6, the authors performed bleaching followed by $\mathrm{pH}$ adjustment to 4 with citric acid $(0.5 \mathrm{~mol} / \mathrm{L})$, the values were $L^{*} 68.91, \mathrm{a}^{*}-2.61$ and $\mathrm{b}^{*} 24.6$.

\subsection{Determination of the minerals sodium ( $\mathrm{Na})$ and potassium $(\mathrm{K})$}

The addition of psyllium in banana pulp resulted in a significant increase in the levels of minerals $\mathrm{Na}$ and $\mathrm{K}$, as can be seen in Table 3.

Table 3. Average concentration for $\mathrm{K}$ and $\mathrm{Na}$ in banana pulp.

\begin{tabular}{lll}
\hline Sample & K (mg/g) & $\mathrm{Na}(\mathrm{mg} / \mathrm{g})$ \\
\hline Banana pulp with psyllium & $405.33 \pm 12.85^{\mathrm{a}}$ & $4.33 \pm 0.15^{\mathrm{a}}$ \\
Banana pulp & $368 \pm 20^{\mathrm{b}}$ & $1.36 \pm 0.41^{\mathrm{b}}$ \\
\hline
\end{tabular}

Different letters on the same line indicate that there was a significant difference by the Tukey test $(\mathrm{p}<0.05)$.

Source: Authors.

In this study, we verified the concentration of the minerals potassium and sodium in psyllium and the results showed $861 \mathrm{mg} / 100 \mathrm{~g}$ for potassium and $60 \mathrm{mg} / 100 \mathrm{~g}$ for sodium. These results are in agreement with those found by Chong, Ball, McRae, and Packer (2019) who, when analyzing the psyllium mineral contents found $805 \pm 2.3(\mathrm{mg} / 100 \mathrm{~g}$ ) for potassium and $62.3 \pm 2,2(\mathrm{mg} / 100 \mathrm{~g})$ for sodium.

It is possible to observe, as shown in Table 3, that there was a significant difference in the value of concentrations for $\mathrm{K}$ and $\mathrm{Na}$ in banana pulp with psyllium. The increase in the content of these minerals in the product confirms that psyllium is a fiber with high potassium content, as cited by Bukhsh, Malik, and Ahmad (2007); Guo, Cui, Wang, \& Christopher Young (2008). It can be observed that the addition of $3 \mathrm{~g}$ of fiber provided a $10.14 \%$ increase in potassium content and $218.38 \%$ increase in sodium content in the pulp with the addition of psyllium. 
Potassium is the most abundant mineral in bananas (Dotto et al., 2019; Etienne et al., 2013). When checking some studies with several banana cultivars, it was found that mineral concentrations are variable as to the type of cultivar and increase according to the stage of maturation (Yap et al., 2017).

In this work, the result for potassium in $100 \mathrm{~g}$ of banana pulp was similar to those found by Bugaud et al. (2013) for the cultivar "Yangambi" with potassium content in $338 \mathrm{mg}$. In the studies of Aquino, Carlos, Salomão, and Siqueira (2014) the banana of the cultivar "Prata" presented $317 \mathrm{mg}$ and in the studies of Yap et al. (2017) with $343 \mathrm{mg}$ in the cultivar "Cavendish".

The banana has naturally low $\mathrm{Na}$ content and has not been found in the literature to date studies showing the concentration of this mineral in the pulp. Although the addition of psyllium increased the concentration of $\mathrm{Na}$, it is still considered a low concentration, because according to the DRIs (Dietary Reference Intakes) the consumption of Na should be less than $2300 \mathrm{mg} /$ day, and the concentration of this mineral in the added pulp of psyllium was $0.18 \%$ compared to that recommended by DRI.

Some studies have related fiber consumption to cardioprotective functions and blood pressure control such as chia (Melo, Machado, \& Oliveira, 2019; Ullah et al., 2016), flaxseed (Khalesi, Irwin, \& Schubert, 2015; Ursoniu, Sahebkar, Andrica, Serban, \& Banach, 2016), psyllium (Solà et al., 2010), but the biological mechanisms involved in lowering blood pressure are not fully understood in the literature.

Chia, flaxseed and psyllium were found to have good amounts of potassium and low sodium content. Kowaleski et al. (2020) found a total of $450 \pm 70 \mathrm{mg} / 100 \mathrm{~g}$ of potassium and $72 \pm 13 \mathrm{mg} / 100 \mathrm{~g}$ of sodium in chia, Deme, Haki, Retta, Woldegiorgis and Geleta (2017) found a total of 502 to 732 in linseed. $\mathrm{mg} / 100 \mathrm{~g}$, the levels differed according to the cultivar. It is found in the Brazilian Table of Composition of Food (Brazilian Food Composition Table) - TACO that the potassium and sodium contents for $100 \mathrm{~g}$ of flaxseed (Linum usitatissimum L.) are $869 \mathrm{mg}$ and $9 \mathrm{mg}$ respectively (TACO, 2011).

After analyzing the data shown on the potassium and sodium contents for the aforementioned fibers, it was observed that the banana pulp added psyllium has potassium contents very similar to these studies, but the sodium contents were lower, being an ideal food source option for hypertensive people.

Several physiological mechanisms have been proposed for the effect of reducing blood pressure related to soluble fibers (Khan et al., 2018), however, to date, no relationship has been found in the literature between minerals in soluble fibers and blood pressure regulation. One hypothesis for the beneficial effect of these soluble fibers in relation to blood pressure control may be related to their high potassium content and low sodium content.

\subsection{Bioaccessibility of minerals by in vitro digestion}

The results of the concentrations of the minerals $\mathrm{K}$ and Na are shown in Table 4.

Table 4. Result of bioaccessibility (expressed as $\%$ of total concentration) of potassium and sodium in banana pulp

\begin{tabular}{lll}
\hline Minerals & Banana pulp & $\begin{array}{l}\text { Banana pulp with } \\
\text { psyllium }\end{array}$ \\
\hline $\mathrm{K}$ & $40.66 \pm 1.15^{\text {a }}$ & $39.33 \pm 1.52^{\text {a }}$ \\
$\mathrm{Na}$ & $92.33 \pm 0.57^{\text {a }}$ & $92.33 \pm 0.57^{\text {a }}$ \\
\hline
\end{tabular}

Data are presented as mean $\pm \mathrm{SD}(n=3)$.

Different letters on the same line indicate that there was a significant difference by the Tukey test $(\mathrm{p}<0.05)$.

Source: Authors. 
In this study, the white analytical was used to indicate the concentrations of minerals $\mathrm{K}$ and $\mathrm{Na}$ that could interfere with the results. For the bioaccessibility of $\mathrm{Na}$, a high concentration of absorption was revealed. There are few studies on the bioaccessibility of sodium and potassium.

According to the literature, the absorption of nutrients will be hardly at $100 \%$, the absorption of minerals can be affected by several inherent factors, such as the presence of mineral antinutrients (phytic acid, polyphenols and dietary fiber) and physical barriers (surrounding macronutrients and cell wall) (Rousseau, Kyomugasho, Celus, Hendrickx, \& Grauwet, 2020).

As can be seen in Table 4, there was no significant difference in mineral concentrations resulting from in vitro digestion simulation between pulps with or without psyllium addition. The bioaccessibility of $\mathrm{K}$ was on average $40.66 \%$ for the pulp with added psyllium and $39.33 \%$ for the pulp without added psyllium and $\mathrm{Na} 92.33 \%$ for both pulps, this means that when ingesting $100 \mathrm{~g}$ of frozen banana pulp added psyllium at the end of digestion possibly the organism will absorb 189.13 $\mathrm{mg}$ of $\mathrm{K}$ and $3.99 \mathrm{mg}$ of $\mathrm{Na}$ and when ingesting the pulp without added psyllium the addition of psyllium the absorption content of $\mathrm{K}$ will be around $144.74 \mathrm{mg}$ and stop at $1.25 \mathrm{mg}$, as can be verified in Table 2 .

Beasley et al. (2020) When analyzing the nutrient intake of elderly women, they found that more than half of the participants were not meeting the consumption guidelines for potassium. The authors stressed the need to identify effective approaches to increase nutrient intake provided in the guidelines. As already reported in this work, adequate intake of $\mathrm{K}$ and $\mathrm{Na}$ are related to blood pressure control and insufficient intake of $\mathrm{K}$ increases the risk of cardiovascular disease (Adrogué \& Madias, 2014).

Although $\mathrm{K}$ is part of the composition of almost all foods, the study on its bioaccessibility is rare, there are more published studies on the bioaccessibility of the minerals iron, zinc and copper. Similar result to this study was found Schulz et al. (2017) when evaluating the mineral contents of the juçara fruit, the authors verified that the $\mathrm{K}$ was the mineral with the highest quantities and the Na presented very low quantities. After simulating digestion in vitro they verified a bioaccessibility of potassium of $40 \%$ to $46 \%$ depending on the stage of maturation of the fruit. Bioaccessibility of Na has not been determined. According to the authors, the intake of $100 \mathrm{~g}$ of juçara fruit pulp corresponds to $4-5 \%$ of the daily needs for $\mathrm{K}$, as directed by DRI.

Pereira et al. (2018), analyzed the content of minerals and their bioaccessibility in blackberry, raspberry, and blueberry. $\mathrm{K}$ was the most abundant mineral, but they could not determine the bioaccessibility content due to the reagents having large amounts of potassium in the formulation and the fraction released by the sample (hydrolysate) was very small.

According to the DRIs, potassium intake for people over the age of 19 should be $2600 \mathrm{mg}$ / day for women and 3400 $\mathrm{mg} /$ day for men. Sodium intake guidance for people over the age of 19 should be at most $2300 \mathrm{mg} /$ day to prevent the risk of chronic diseases (Institute of Medicine, 2019).

When analyzing the guidelines of the DRI for people over 19 years old, it can be observed that the frozen banana pulp added with psyllium will contribute to the intake of $\mathrm{K}$ in $7.27 \%$ for women and $5.56 \%$ for men, and the intake of $\mathrm{Na}$ in $0.17 \%$.

\section{Conclusion}

The results represent an important contribution to the area of nutrition, as it provides information on the approximate amounts of minerals that are absorbed in this product.

It was possible to verify that the addition of psyllium in the pulp presented a higher content of Mineral K. Our study suggests that the consumption of $100 \mathrm{~g}$ of the added frozen banana pulp of psyllium may contribute to the increase in $\mathrm{K}$ intake and presents health benefits as a lower risk of developing cardiovascular disease due to a decrease in the risk of hypertension 
and stroke. This pulp meets the requirements to receive the health claim and can contribute to the reduction of LDL cholesterol.

More studies on the bioaccessibility of minerals, especially on $\mathrm{K}$, in fruits and soluble fibers (psyllium, chia, flaxseed, oats) should be carried out, since there are few or no studies in this area.

\section{Acknowledgments}

We thank the Laboratory of Tropical Fruits (LAFRUT) - UFC for carrying out part of the analyzes. This study was funded in part by the Coordination for the Improvement of Higher Education Personnel - Brazil (CAPES) and the National Council for Scientific and Technological Development (CNPq) - Financial Code 001.

\section{References}

Adrogué, H. J., \& Madias, N. E. (2014). The Impact of Sodium and Potassium on Hypertension Risk. Seminars in Nephrology, 34(3), 257-272. https://doi.org/https://doi.org/10.1016/j.semnephrol.2014.04.003

Anderson, J. W., Baird, P., Jr, R. H. D., Ferreri, S., Knudtson, M., Koraym, A., \& Williams, C. L. (2009). Health benefits of dietary fiber, 67(4), 188-205. https://doi.org/10.1111/j.1753-4887.2009.00189.x

Aquino, César Fernandes, Salomão, Luiz Carlos Chamhum, Siqueira, Dalmo Lopes de, Cecon, Paulo Roberto, \& Ribeiro, Sônia Machado Rocha. (2014). Teores de minerais em polpas e cascas de frutos de cultivares de bananeira. Pesquisa Agropecuária Brasileira, 49(7), 546-553.

Beasley, J. M., Rillamas-Sun, E., Tinker, L. F., Wylie-Rosett, J., Mossavar-Rahmani, Y., Datta, M., \& LaCroix, A. Z. (2020). Dietary Intakes of Women's Health Initiative Long Life Study Participants Falls Short of the Dietary Reference Intakes. Journal of the Academy of Nutrition and Dietetics, 120(9), 1530 1537. https://doi.org/https://doi.org/10.1016/j.jand.2020.05.001

Bennett, J. E., Stevens, G. A., Mathers, C. D., Bonita, R., Rehm, J., Kruk, M. E., \& Ezzati, M. (2018). NCD Countdown 2030: worldwide trends in noncommunicable disease mortality and progress towards Sustainable Development Goal target 3.4. The Lancet, 392(10152), 1072-1088. https://doi.org/10.1016/S0140-6736(18)31992-5

Bernstein, A. M., Titgemeier, B., Kirkpatrick, K., Golubic, M., \& Roizen, M. F. (2013). Major cereal grain fibers and psyllium in relation to cardiovascular health. Nutrients, 5(5), 1471-1487. https://doi.org/10.3390/nu5051471

Brasil. Resolução n 18, de 30 de abril de. (1999). Aprova o Regulamento Técnico que Estabelece as Diretrizes Básicas para Análise e Comprovação de Propriedades Funcionais e ou de Saúde Alegadas em Rotulagem de Alimentos. Brasília: Diário Oficial da República Federativa do Brasil 03 nov. 1999.

Brasil. Ministério da Saúde. Secretaria de Vigilância Sanitária. Resolução RDC n ${ }^{\circ}$ 8, de 06 de março de 2013. Dispõe sobre a aprovação de uso de aditivos alimentares para produtos de frutas e de vegetais e geleia de mocotó. Diário Oficial da República Federativa do Brasil, Brasília, n.46, 08 mar. 2013.

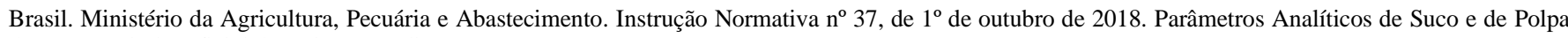
de Frutas. Diário Oficial da União. Brasília, DF, 08 out. 2018

Bugaud, C., Cazevieille, P., Daribo, M.-O., Telle, N., Julianus, P., Fils-Lycaon, B., \& Mbéguié-A-Mbéguié, D. (2013). Rheological and chemical predictors of texture and taste in dessert banana (Musa spp.). Postharvest Biology and Technology, 84, 1-8. https://doi.org/https://doi.org/10.1016/j.postharvbio.2013.03.020

Bugaud, C., Maraval, I., Daribo, M.-O., Leclerc, N., \& Salmon, F. (2016). Optimal and acceptable levels of sweetness, sourness, firmness, mealiness and banana aroma in dessert banana (Musa sp.). Scientia Horticulturae, 211, 399-409. https://doi.org/https://doi.org/10.1016/j.scienta.2016.09.016

Bukhsh, E., Malik, S., \& Ahmad, S. (2007). Estimation of Nutritional Value and Trace elements Content of Carthamus oxyacantha, Eruca stiva and Plantago ovata. Pakistan Journal of Botany, 39, 1181-1187.

Chong, R. W. W., Ball, M., McRae, C., \& Packer, N. H. (2019). Comparing the chemical composition of dietary fibres prepared from sugarcane, psyllium husk and wheat dextrin. Food Chemistry, 298, 125032. https://doi.org/https://doi.org/10.1016/j.foodchem.2019.125032

Deme, T., Haki, G. D., Retta, N., Woldegiorgis, A., \& Geleta, M. (2017). Mineral and Anti-Nutritional Contents of Niger Seed (Guizotia abyssinica (L.f.) Cass., Linseed (Linumusitatissimum L.) and Sesame (Sesamumindicum L.) Varieties Grown in Ethiopia. Foods (Basel, Switzerland), 6(4). https://doi.org/10.3390/foods6040027

Dotto, J., Matemu, A. O., \& Ndakidemi, P. A. (2019). Nutrient composition and selected physicochemical properties of fifteen Mchare cooking bananas: A study conducted in northern Tanzania. Scientific African, 6, e00150. https://doi.org/https://doi.org/10.1016/j.sciaf.2019.e00150

Etienne, A., Génard, M., Bancel, D., Benoit, S., \& Bugaud, C. (2013). A model approach revealed the relationship between banana pulp acidity and composition during growth and post harvest ripening. Scientia Horticulturae, 162, 125-134. https://doi.org/https://doi.org/10.1016/j.scienta.2013.08.011

Ezzati, M., Zhou, B., Bentham, J., Di Cesare, M., Bixby, H., Danaei, G., \& Cisneros, J. Z. (2018). Contributions of mean and shape of blood pressure distribution to worldwide trends and variations in raised blood pressure: A pooled analysis of 1018 population-based measurement studies with 88.6 million participants. International Journal of Epidemiology, 47(3), 872-883i. https://doi.org/10.1093/ije/dyy016 
Fernández-García E, Carvajal-Lérida I, Pérez-Gálvez A. In vitro bioaccessibility assessment as a prediction tool of nutritional efficiency. Nutr Res. 2009 Nov;29(11):751-60.

Figueroa, L. E., \& Genovese, D. B. (2019). Fruit jellies enriched with dietary fibre: Development and characterization of a novel functional food product. Lwt, 111(May), 423-428. https://doi.org/10.1016/j.1wt.2019.05.031

Franco, E., Aparecida, N., Sanches-silva, A., Ribeiro-santos, R., Ramos, N., \& Melo, D. (2020). Trends in Food Science \& Technology Psyllium ( Plantago ovata Forsk ): From evidence of health bene fi ts to its food application. Trends in Food Science \& Technology, 96(November 2018), 166-175. https://doi.org/10.1016/j.tifs.2019.12.006

Guo, Q., Cui, S. W., Wang, Q., \& Christopher Young, J. (2008). Fractionation and physicochemical characterization of psyllium gum. Carbohydrate Polymers, 73(1), 35-43. https://doi.org/10.1016/j.carbpol.2007.11.001

Khalesi, S., Irwin, C., \& Schubert, M. (2015). Flaxseed Consumption May Reduce Blood Pressure: A Systematic Review and Meta-Analysis of Controlled Trials. The Journal of Nutrition, 145(4), 758-765. https://doi.org/10.3945/jn.114.205302

Khan, K., Jovanovski, E., Ho, H. V. T., Marques, A. C. R., Zurbau, A., Mejia, S. B., \& Vuksan, V. (2018). The effect of viscous soluble fiber on blood pressure: A systematic review and meta-analysis of randomized controlled trials. Nutrition, Metabolism and Cardiovascular Diseases, 28(1), 3-13. https://doi.org/10.1016/j.numecd.2017.09.007

Kowaleski, J., Quast, L. B., Steffens, J., Lovato, F., Rodrigues dos Santos, L., Zambiazi da Silva, S., \& Felicetti, M. A. (2020). Functional yogurt with strawberries and chia seeds. Food Bioscience, 37, 100726. https://doi.org/https://doi.org/10.1016/j.fbio.2020.100726

Insitute of Medicine. Dietary Reference Intakes for Water, Potassium, Sodium, Chloride, and Sulfate. Food and Nutrition Board: National Academy Press, Washington, DC, 2004.

Institute of Medicine, Food and Nutrition Board. Dietary Reference Intakes for Sodium and Potassium. The National Academies Press, Washington, DC (2019) Md Nor, S., \& Ding, P. (2020). Trends and advances in edible biopolymer coating for tropical fruit: A review. Food Research International, 134(March), 109208. https://doi.org/10.1016/j.foodres.2020.109208

Melo, D., Machado, T. B., \& Oliveira, M. B. P. P. (2019). Chia seeds: an ancient grain trending in modern human diets. Food \& Function, 10(6), 3068-3089. https://doi.org/10.1039/c9fo00239a

Molina-Ramírez, C., Cañas-Gutiérrez, A., Castro, C., Zuluaga, R., \& Gañán, P. (2020). Effect of production process scale-up on the characteristics and properties of bacterial nanocellulose obtained from overripe Banana culture medium. Carbohydrate Polymers, 240 , 116341. https://doi.org/https://doi.org/10.1016/j.carbpol.2020.116341

Olde Engberink, R. H. G., van den Born, B. J. H., Peters-Sengers, H., \& Vogt, L. (2020). Long-term potassium intake and associated renal and cardiovascular outcomes in the clinical setting. Clinical Nutrition, (xxxx). https://doi.org/10.1016/j.clnu.2020.03.026

OMS. Prevention of recurrent heart attacks and strokes in low and middle income populations: Evidence-based recommendations for policy makers and health professionals. Geneva, World Health Organization (WHO), 2003 (http://www.who.int/cardiovascular_diseases/resources/pub0402/en/).

Orlando, E. A., Rebellato, A. P., Silva, J. G. S., Andrade, G. C., \& Pallone, J. A. L. (2020). Sodium in different processed and packaged foods: Method validation and an estimative on the consumption. Food Research International, 129, 108836. https://doi.org/https://doi.org/10.1016/j.foodres.2019.108836

Orqueda, M. E., Torres, S., Verón, H., Pérez, J., Rodriguez, F., Zampini, C., \& Isla, M. I. (2021). Physicochemical, microbiological, functional and sensory properties of frozen pulp of orange and orange-red chilto (Solanum betaceum Cav.) fruits. Scientia Horticulturae, 276 , 109736. https://doi.org/https://doi.org/10.1016/j.scienta.2020.109736

Pereira, A. M., Bonemann, D. H., Scherdien, S. H., Ávila, B. P., Antunes, I. F., Ribeiro, A. S., \& Gularte, M. A. (2020). Evaluation of total and bioaccessible concentration of minerals in creole beans. Journal of Food Composition and Analysis, 94, 103622. https://doi.org/https://doi.org/10.1016/j.jfca.2020.103622

Pereira, C. C., do Nascimento da Silva, E., de Souza, A. O., Vieira, M. A., Ribeiro, A. S., \& Cadore, S. (2018). Evaluation of the bioaccessibility of minerals from blackberries, raspberries, blueberries and strawberries. Journal of Food Composition and Analysis, 68, 73-78. https://doi.org/https://doi.org/10.1016/j.jfca.2016.12.001

Rao, M. R. P., Warrier, D. U., Gaikwad, S. R., \& Shevate, P. M. (2016). Phosphorylation of psyllium seed polysaccharide and its characterization. International Journal of Biological Macromolecules, 85, 317-326. https://doi.org/https://doi.org/10.1016/j.ijbiomac.2015.12.043

Raymundo, A., Fradinho, P. P., \& Nunes, M. C. (2014). Effect of Psyllium fibre content on the textural and rheological characteristics of biscuit and biscuit dough. Bioactive Carbohydrates and Dietary Fibre, 3(2), 96-105. https://doi.org/10.1016/j.bcdf.2014.03.001

Rousseau, S., Kyomugasho, C., Celus, M., Hendrickx, M. E. G., \& Grauwet, T. (2020). Barriers impairing mineral bioaccessibility and bioaccessibility in plant-based foods and the perspectives for food processing. Critical Reviews in Food Science and Nutrition, 60(5), 826-843. https://doi.org/10.1080/10408398.2018.1552243

Schulz, M., Biluca, F. C., Gonzaga, L. V., Borges, G. da S. C., Vitali, L., Micke, G. A., \& Fett, R. (2017). Bioaccessibility of bioactive compounds and antioxidant potential of juçara fruits (Euterpe edulis Martius) subjected to in vitro gastrointestinal digestion. Food Chemistry, 228, 447-454. https://doi.org/https://doi.org/10.1016/j.foodchem.2017.02.038

Sheng, Z. W., Ma, W. H., Jin, Z. Q., Bi, Y., Sun, Z. G., Dou, H. T., \& Han, L. N. (2010). Investigation of dietary fiber, protein, vitamin E and other nutritional compounds of banana flower of two cultivars grown in China. African Journal of Biotechnology, 9(25), 3888-3895. https://doi.org/10.4314/ajb.v9i25

Solà, R., Bruckert, E., Valls, R. M., Narejos, S., Luque, X., Castro-Cabezas, M., ... Anguera, A. (2010). Soluble fibre (Plantago ovata husk) reduces plasma 
Research, Society and Development, v. 10, n. 8, e10410816949, 2021

(CC BY 4.0) | ISSN 2525-3409 | DOI: http://dx.doi.org/10.33448/rsd-v10i8.16949

low-density lipoprotein (LDL) cholesterol, triglycerides, insulin, oxidised LDL and systolic blood pressure in hypercholesterolaemic patients: A randomised trial. Atherosclerosis, 211(2), 630-637. https://doi.org/10.1016/j.atherosclerosis.2010.03.010

Sukhija, S., Singh, S., \& Riar, C. S. (2016). Analyzing the effect of whey protein concentrate and psyllium husk on various characteristics of biodegradable film from lotus (Nelumbo nucifera) rhizome starch. Food Hydrocolloids, 60, 128-137. https://doi.org/https://doi.org/10.1016/j.foodhyd.2016.03.023

Sun, H., \& Sun, M. (2018). Age- and gender-dependent associations of blood pressure and serum sodium and potassium—renal and extrarenal regulations. Journal of the American Society of Hypertension, 12(5), 392-401. https://doi.org/https://doi.org/10.1016/j.jash.2018.03.005

TACO - Tabela brasileira de Composição de Alimentos/ NEPA. UNICAMP. 4ª edição. rev. e ampl. NEPA- UNICAMP. 2011.

Thakur, J. S., Paika, R., \& Singh, S. (2020). Burden of noncommunicable diseases and implementation challenges of National NCD Programmes in India. Medical Journal Armed Forces India, 76(3), 261-267. https://doi.org/10.1016/j.mjafi.2020.03.002

Ullah, R., Nadeem, M., Khalique, A., Imran, M., Mehmood, S., \& Javid, A. (2016). Nutritional and therapeutic perspectives of Chia ( Salvia hispanica L .): a review. Journal of Food Science and Technology, 53(April), 1750-1758. https://doi.org/10.1007/s13197-015-1967-0

Ursoniu, S., Sahebkar, A., Andrica, F., Serban, C., \& Banach, M. (2016). Effects of flaxseed supplements on blood pressure: A systematic review and metaanalysis of controlled clinical trial. Clinical Nutrition, 35(3), 615-625. https://doi.org/https://doi.org/10.1016/j.clnu.2015.05.012

Weaver, C. (2013). White Vegetables: A Forgotten Source of Nutrients Potassium and Health 1 - 3. American Society for Nutrition, 4, 3685-3775. https://doi.org/10.3945/an.112.003533.smoking

WHO Guideline: potassium intake for adults and children. World Health Organization (WHO), Geneva (2012)

Yap, M., Fernando, W. M. A. D. B., Brennan, C. S., Jayasena, V., \& Coorey, R. (2017). LWT - Food Science and Technology The effects of banana ripeness on quality indices for puree production. LWT - Food Science and Technology, 80, 10-18. https://doi.org/10.1016/j.1wt.2017.01.073 